Speaking of Jews 
This page intentionally left blank 


\section{Speaking of Jews}

Rabbis, Intellectuals, and the Creation of an American Public Identity

\section{Lila Corwin Berman}

ㄸ

UNIVERSITY OF CALIFORNIA PRESS 
University of California Press, one of the most distinguished university presses in the United States, enriches lives around the world by advancing scholarship in the humanities, social sciences, and natural sciences. Its activities are supported by the UC Press Foundation and by philanthropic contributions from individuals and institutions. For more information, visit www.ucpress.edu.

Monroe image [figure II] by Milton H. Greene () 2008 Joshua Greene, www.archiveimages.com.

University of California Press

Berkeley and Los Angeles, California

University of California Press, Ltd.

London, England

(C) 2009 by The Regents of the University of California

Library of Congress Cataloging-in-Publication Data

Berman, Lila Corwin, 1976-

Speaking of Jews : rabbis, intellectuals, and the creation of an American public identity / Lila Corwin Berman.

p. $\mathrm{cm}$.

Includes bibliographical references and index.

ISBN 978-0-520-25680-4 (cloth : alk. paper) -

ISBN 978-0-520-2568I-I (pbk. : alk. paper)

I. Jews-United States-Identity. 2. Jews-United States-Social conditions - 2oth century. 3. Jewish leadership-United StatesHistory -20th century. 4. Judaism and the social sciences. 5. Religion and sociology-United States. 6. United States-Ethnic relations.

I. Title.

EI84.36.E84B47 2008

305.6'9609730904-dc22

2008025974

Manufactured in the United States of America

$\begin{array}{llllllllll}\text { I8 } & \text { I7 } & \text { I6 } & \text { I5 } & \text { I4 } & \text { I3 } & \text { I2 } & \text { II } & \text { IO } & \text { O9 }\end{array}$

IO $\quad 9 \quad \begin{array}{llllllll}8 & 7 & 6 & 5 & 4 & 3 & 2 & \text { I }\end{array}$

This book is printed on Natures Book, which contains 30\% post-consumer waste and meets the minimum requirements of ANSI/NISO Z39.48-1992 (R 1997) (Permanence of Paper). 